\title{
Karl Barth's role in church and politics from 1930 to 1935
}

\author{
André J Groenewald ${ }^{1}$ \\ Pastor: Presbyterian Church of Scotland \\ Edinburgh, Scotland
}

\begin{abstract}
Karl Barth saw in natural theology a threat to the church of Christ. He was convinced that the so-called "German Christians" under the influence of the National Socialist Party practised natural theology. He advocated the need for the church of Christ to be church according to the Word of God. The church can be true church of Christ when it listens to and obeys the true calling of God. Barth's critique of an exclusive "Volkskirche" can serve as a corrective for the definition of the Nederduitsch Hervormde Kerk as a "volkskerk".
\end{abstract}

\section{INTRODUCTION}

The conflict within the German church caused by the so-called "German Christians'" sympathy for and support of the National Socialist Party influenced Karl Barth's ecclesiology. In this article, I will provide the reader with an overview of the circumstances that led Barth to criticize "natural theology" and to develop his notion of the essence and task of the church of Christ in the world in the period 1930 to 1935 (cf Barth 1933c:22; see Barth 1933b:7; see Barth 1933d:20). Even after this period (1930-1935), he did not alter his views on the church (cf Barth 1939b, cf Barth 1944, see Barth 1945).

\section{THE CHURCH STRUGGLE IN GERMANY FROM 1930 TO 1935}

With the formulation of Article 24 in 1920, the National Socialist Party made its intentions clear, namely:

\footnotetext{
${ }^{1}$ The author expresses his sincere gratitude to the Nederduitsch Hervormde Kerk van Afrika and the Faculty of Theology, University of Pretoria for the financial support given to him to attend the International Reformed Theological Institute's meeting in Cluj-Naponica, Romania from 3 to 8 July 2007.
} 
- That any religious confession would be tolerated in the German state "providing that they do not endanger its existence or offend the German race's sense of decency and morality" (Matheson 1981:1);

- The National Socialist Party "stands for a positive Christianity, without binding itself denominationally to a particular confession" (Matheson 1981:1; see Scholder 1988a:192);

- It would fight "against the Jewish-materialistic spirit at home and abroad ..." (Matheson 1981:1).

A group called the "German Christians" (see Barth 1969:45-47) began to emerge in the German church. They did everything in their power to support the National Socialist Party and to mobilize other Protestant Christians to do the same. In fact, they were known as the "Faith Movement of German Christians". On 6 June 1932 they accepted their first manifesto (see Scholder 1988a:208-210). The important issues reflected in the manifesto that would have severe consequences for the Protestant Church in the years to come, were the following:

- "Unification of the 29 churches gathered together under the 'German Protestant Church Federation' into one Protestant Reich Church ..." (Matheson 1981:5; Scholder 1988a:208);

- The construction of a "dynamic national church (Volkskirche), which expresses the living faith of our people" (Matheson 1981:5; Scholder 1988a:208);

- "Racial admixture" would be prohibited (Matheson 1981:5; Scholder 1988a:208);

- Mission to the Jews is to be seen as a threat to the German culture (Scholder 1988a:209; see Smid 1990).

After the elections of 14 September 1930 when Hitler's party became the second strongest party in the Reich, everything changed. It followed immediately after the crash of the New York Stock Exchange (1929), and world economies were in crisis. The number of unemployed in Germany rose from 2.8 million in January 1929 to 3.2 million in January 1930, a situation which favoured the National Socialists.

On 30 January 1933 Adolph Hitler, leader of the National Socialist Party, became the Chancellor of Germany (cf Busch 1976:235; see Scholder 1988a:221). He wanted to unite the different regional Protestant churches into 
one "Church of the Reich" (cf Barth 1933a:8; see Scholder 1988a:223). It became a reality on 23 July 1933 when the German Christians won "threequarters of the vote" and the German Evangelical Church was formed (Barth 1933b:10-16; Barth 1933c:3-4; Barth 1933d:21; Green 1989:148). The German Evangelical Church became even more assimilated with the state when Hitler's newly appointed adviser on Protestant church affairs, Ludwig Müller, was elected as "Reichsbischof" on 27 September 1933 (cf Barth 1933a:15-23; Barth 1933e:8-9; Barth 1934b:1; Matheson 1981:38; see Scholder 1988a:293, 310, 520-522). He had full authority as far as Church affairs were concerned (Barth 1934b:7-9; cf Busch 1976:239; cf Green 1989:148).

In opposition to the emerging German Christians, another group, known as the "Pastors' Emergency League" under the leadership of Martin Niemöller (cf Barth 1933e:5; cf Matheson 1981:36-38; see Niemöller 1939), became evident in the German Evangelical Church. Later on they became known as "The Confessing Church". They rejected the German Christians' manifesto and in particular the "Aryan Paragraph", which excluded cular Christian Jews from becoming members of the German Evangelical Church (cf Barth 1933d:3-7). After its suspension on 16 November 1933 the German Evangelical Church reinstated this paragraph on 4 January 1934 (Matheson 1981:41-42). On 15 April 1934 the popular anti-German Christian bishop Wurm of the Württemberg Provincial Synod was dismissed. He did not support the German Christians' cause. This dismissal paved the way for the provincial Barmen Synod that took place from 29 to 31 May 1934. With the Barmen declaration all the delegates from the Lutheran, Reformed and United Churches took a unified stance against the German Christians of the German Evangelical Church (see Scholder 1988b:122-171). Karl Barth was mainly responsible for the formulation of this declaration. Barmen was to become a beacon to the Confessing Church in the years to come and has become one of the classic confessions of modern Christianity (see Sauter 2006:7-18). However, Barth later felt that it had one major failure: the Jewish question was not a decisive feature of his draft of the text. "Of course in 1934 no text in which I had done that would have been acceptable even to the Confessing Church, given the atmosphere that there was then. But that does not excuse me for not having at least gone through the motions of fighting" (Barth in Bowden 1983:59).

At the second synod of the Confessing Church, held on 19 and 20 October 1934 at Berlin-Dahlem, the delegates decided to go one step further in creating "an emergency church government, based on congregational and synodal support" (Matheson 1981:49; see Busch 1976:267). Their effort was 
answered by the Nazis' abolishing the Protestant Churches' freedom of expression on 12 November 1934 and on 6 May 1935. Until the end of the war, the Nazis would continue to constrain the influence of the "Confessing Church", while maintaining their control over the German Evangelical Church. Barth was temporarily suspended from the University of Bonn on 26 November 1934 after he had refused to "swear an unconditioned oath of allegiance to the führer [sic]" (Barth 1969:47).

On 18 December 1934 after his appearance before the commission of state in Köln, the rector of Bonn and the minister of culture informed him that he was suspended until further notice. As from 1 March 1935 Barth was not even allowed to speak and lecture in public in Germany (see Busch 1976:272). On 22 June 1935 the University of Bonn finally dismissed Barth as professor. From 1936 he was not allowed to publish any article or book in Germany (Stoevesandt 1984:9). Fortunately for Barth, he was re-appointed as professor at the University of Basel on 25 June 1935. Those who opposed the Nazi government were either moved to other parishes, as was the case with Ernst Wolf, or were dismissed, as was the case with Friedrich Horst.

\section{BARTH'S REACTION TO THE SITUATION IN THE CHURCH}

Barth, who from 1930 was a professor in Bonn, reacted in many ways. Firstly he delivered sermons and lectures that were published as articles in different journals or booklets. Secondly, he joined the theologians and pastors in the "Confessing Church", criticizing the influence of the governing Nazis on the theology of German Christians. In protest to the growing madness and the threat to democracy, he even became a member of the Social Democratic Party on 1 May 1931 (see Busch 1976:230).

In an attempt to deal with Barth's insights from 1930 to1935, I will examine his contribution in three sections, namely:

- His theological method and epistemology;

- His critique of the German Christians;

- His views on the church and her position in society;

\subsection{His theological method}

Barth criticized any human venture by which knowledge of God is claimed. He rejected "natural theology" on the basis of his conviction that humans are solely dependent on God's grace (Barth 1946:61; cf Barth 1933f:312-314; see Barth 1935b:24; see Molnar 2005:53, 63-65; see Webster 2005:20). His strong feelings against "natural theology" would become even more prominent in the 
years to come, especially in his conviction that the "German Christians" openly practised "natural theology" (Barth 1933d:5, 20; cf Green 1989:151; cf Hunsinger 2000:80; cf McCormack 1995:15; cf Molnar 2005:69-70; cf Price 2002:69; see Trowitzsch 2006:5). He accused the Nazis of Fascism that practised "natural theology" (Barth 1957:94).

From July to October 1930 he started to work on a book on Anselm. In August 1931 he finished this work, which he called Fides quaerens intellectum, after the most important statement of Anselm's. Anselm wanted to prove the existence of God by means of a certain method. Barth continued with his own method used in Der Römerbrief (1922). In Der Römerbrief (1922) he made use of dialectics and analogies to speak of God (see Lindsay 2001:122-124). In his book, Fides quaerens intellectum, he used analogy to express the relationship between God and the human race. The method Anselm used, largely coincided with Barth's own thinking about God. Anselm, concurring with Barth, said that knowledge of God begins with faith (Barth 1982:131). It is through prayer that we gain faith. And in every moment of faith we come to realize who God really is. Hence this faith leads to knowledge of God (Credo ut intelligam) (Barth [1931] 1981:20-21; cf Mostert 2001:78; see Webster 2005:28). Therefore, the theologian cannot know God without faith. And even if he/she has faith, he/she must wait for God to reveal Himself, as he has done in Jesus Christ (cf Holmes 2007:66-67; cf Mostert 2001:75; see Hunsinger 2002:316-338). Barth differs from Anselm on the issue of the latter's treatment of the Bible and the Credo (the Confessions of Faith) as "revealed-ness", as events that have already been completed (Barth [1931] 1981:23). With his famous threefold meanings and usages of the Word of God, Barth shows that this is not the case. God still reveals himself every time a human opens him/herself to his Word in faith. But in agreement with Anselm, Barth concludes that knowledge of God fully depends on God's gracious decision (see Barth [1931] 1981:101-102). According to Barth "natural theology" cannot lead to knowledge of God. Knowledge principally means re-cognition. Thinking means post- contemplation, cogitare arises from cogere (knowing/recognizing) divine revelation (Barth 1982:136). With this book Barth takes a firm stand against any theology that relies on "natural theology".

Barth would not tolerate any theology that extends the revelation of God in Jesus Christ to also include His revelation through nature or the nation, in this case the German nation. This becomes clear in his reaction to Article 24 of the National Socialist Party as expressed in his article Quousque tandem ...? written in 1930. In this article Barth reacts to the opening sentences of an article by professor D Schneider in the Kirchliches Jahrbuch für die evangelische Kirche in Deutschland in which he reflects on the then present 
situation (Germany after Word War I). Professor Schneider agrees with the Präses dr Wolff that the Evangelical Church recovered from the devastation of the past because there still remained some church people who were able to save the church and this they achieved because of natural religion. "Gezeigt hat sich, daß der religiöse Gedanke doch tiefer in der deutschen Volksseele verwurzelt war, als nach außen hin in die Erscheinung trat. Das heilige 'Dennoch' hat sich durchgesetzt' (Barth 1930a:1). ${ }^{2}$ According to Barth, by using language such as "da ist Catilina, da is die eigentliche, gefährliche Verschwörung gegen die Substanz der evangelischen Kirche" (Barth 1930a:2). ${ }^{3}$ According to Barth (1930a:2), Professor Schneider is guilty of generalization and language that bears witness to his identity. The leaders of this church reinforce their own ideas through their words and deeds, seeking their own ends and blowing their own trumpets. Their focus is only on themselves, while, God, His Gospel and its message to the people are neglected. This church's preaching will be empty and meaningless, even when he/she utters Jesus' name a thousand times.

\begin{abstract}
Wenn sie "Jesus Christus" sagt, muß und wird man, und wenn sie es tausendmal sagte, ihre eigene Sattheit und Sicherheit hören und sie soll sich nicht wundern, wenn sie mit allem ihrem "Jesus Christus" in den Wind, an der wirklichen Not der wirklichen Menschen vorbeiredet, wie sie am Worte Gottes vorbeigehört, aus aller Mahnungcaution, Tröstung und Lehre der Bibel und der Reformatoren Wasser auf ihre eigenen kleinen Mühlen gemacht hat.
\end{abstract}

(Barth 1930a:6)

In July of the same year, he would repeat these sentiments in a lecture, Die Theologie und der heutige Mensch, given in Frankfurt am Main and in Heidelberg. In this lecture his new method of "faith seeking understanding", or even better Credo ut intelligam, is outlined. In this lecture Barth dealt with the difficulties of presenting theology to modern man. Often theology causes great offence.

\footnotetext{
2 "What has revealed itself is that religious thoughts are deeper entrenched in the German people's soul than what it appears to be from the outside. The holy 'yet' has prevailed".

3 "There is Catilina, the truly dangerous conspiracy against the substance of the evangelical church".

4 "When he/she utters "Jesus Christ", also if uttered a thousand times, what one must and will hear, is one's own conceit and certainty and one should not be astonished to discover that with all the utterances of "Jesus Christ" in the air, the real need of the real human is overlooked, [just] as God's Word is misheard, turning all caution, consolation and teaching of the Bible and the Reformists into water on their own little mill."
} 
According to Barth (1930b), theology is the critical reflection of the Word upon which the church is founded. Theology is a function of the church that is in the world. The ineffectiveness of human thought and language causes the church to experience difficulty in proclaiming the Word of God. In fact, the church cannot proclaim the Word of God. All the church can do, is listen to, serve and obey the Word of God. In so doing, the church must be aware of her shortcomings and failures. The church can only proclaim the Word of God after God has revealed it to her. Theology is the science in terms of which the church gives account of the presupposition of her task. Theology measures the proclamation of the church in terms of the guidelines of the Word of God. Barth calls this guideline an "axioma". "Axiomatische Gewißheit hat ihre Würde vor anderweitiger Gewißheit in ihrer homousie, in ihrem Gleichsein und Zugleichsein mit der Selbstgewißheit des denkenden Subjektes" (Barth (1930b:378). ${ }^{5}$ Proving God's existence belongs to another order. God exists only in his revelation and in faith (Barth 1930b:378). Theology depends on the living Word of God. Theology becomes theology when it lives by the Word of God. Theology must always become what it already is. Every theological statement depends on the revelation of God (Barth 1930b:381).

The "axioma" of theology has a character of reliance. When the Word of God is mentioned, it means revelation. It does not mean timeless truths, but truths in time. "Theologie wagt es, in der Gegenwart und also ohne Erfüllung, ohne Sicherung, damit zu rechnen, da $\beta$ Gott sein Wort sprechen wird, weil sie anerkennt, daß er es schon gesprochen hat" (Barth 1930b:380). ${ }^{6}$ The origin of the church is the revelation of God in Christ. Theology is a reflection of this reminiscence ("Erinnerung"), because without this recollection, there is no faith and no hope. Theological thinking always adheres to the reminiscence of God's revelation in Christ. The embarrassment lies in the fact that the theologian and the believer, as sinful human beings, reflect on this memory in his or her own way. It places a great deal of responsibility on the shoulders of any believer (see McGrath 2007:56).

A third aspect about theology that could be embarrassing to some, lies in the fact that the Word of God is only accessible through faith (Barth 1930b:382). It is not a human venture. It comes from God. After Barth (1930b:385-395) has

\footnotetext{
5 "The worth of axiomatic certainty vis à vis other forms of certainty lies in its homousie/substance, in its similarity and simultaneity with the self-certainty of the thinking subject."

6 "Theology dares to accept in the present and without fulfilment thereof that God will proclaim his word, in the acknowledgement that He had already spoken it."
} 
dealt with the problems theology faces, he offers some of the choices people exercise in view of the said problems, namely:

- to abandon theology as being something of an impossible nature, as D F Strauss did (Barth 1930b:385; see Barth 1939a);

- to change theology to fit into the paradigm of modern man (Barth 1930b:388-392);

- to consolidate theology with other philosophies and theologies such as "natural theology". "Der Schrei nach der 'natürlichen' Theologie ertönt schon an allen Ecken und Enden und das Werk ihrer Neubegründung ist ebenfalls an allen Ecken und Enden und in den verschiedensten Aufmachungen im vollen Gang" (Barth 1930b:395); ${ }^{7}$

- to reject the choices and stand firm on the basis of faith.

In his lecture, Die Theologie und die Mission in der Gegenwart (11 April 1932), he denied that a natural revelation could be/could establish a point of contact between God and the human race. The point of contact lies beyond the reach and power of human speech. It is a miracle of grace that comes from God alone, "wo und wie immer die Sprache anknüpfen möge, ein Wunder und kein Brückenschlag und als Wunder und nicht als erhöhte Natur zu verkündigen ist" (Barth 1932a:214-215). ${ }^{8}$

He would not tolerate the practising of anything that smacked of "natural theology", even to the point of it affecting his friendship with Emil Brunner, a colleague. (Barth 1932b:25-35; 251; Barth 1934e; see Barth 1933f:309, 312). His response in the form of an article, Nein (Barth 1934e; see Meier 1976:175191 to Brunner's publication, Natur und Gnade, published in October 1934) is therefore not unexpected. According to Brunner the living God reaches out to the human race. He then poses the question: How does the revelation of God reach the human race? Is there such a thing as a natural "Anknüpfungspunkt" (point of contact) inside every human being? According to Brunner, the Bible in Romans 1:19, 20 \& 2:14, 15 clearly speaks of the general revelation of God and

\footnotetext{
7 "The call for 'natural' theology rings out in all corners and from all sides and similarly the manifestation of its latest establishment in its various forms is in full swing in all corners and sides."

8 "where and in whatever manner speech takes place, [is] a miracle and not a bridging feat/point of contact, a miracle that is to be proclaimed as a miracle and not as elevated nature."
} 
its call upon the accountability of the human race (cf Brunner [1946] 1972:137). "Der Anknüpfungspunkt ist eben: die auch dem Sünder nicht abhanden gekommene formale imago Dei, das Menschsein des Menschen, die humitas, nach ihren zwei vorhin bezeichneten Momenten: Wortmächtigkeit und Verantwörtlichkeit" (Brunner 1934:18; cf Brunner [1946] 1972:138; see Price 2002:117-119). ${ }^{9}$ Barth (1934e:15-31) accused Brunner of practising "natural theology". It is not within the scope of this article to judge whether or not Barth's accusation is founded. However, it is probably fair to say that Barth may have overreacted in the light of the German church struggle (cf McCormack 1997:15; see Hunsinger 2000:80; see Gijmink 1962:60).

During the course of 1933 Barth continued his critique of "natural theology". In a lecture given in Copenhagen on 10 March and in Aarhus on 12 March 1933 entitled, Das Erste Gebot als Theologische Axiom, he declared that ignorance of and disobedience to the First Commandment is the reason for accepting "natural theology" and "anderen Götter" (other gods) (Barth 1933f:309). The First Commandment is disobeyed when God's revelation is linked to other concepts, such as revelation and reason, revelation and nature. Then theology becomes something else, a human venture without God. It has to judge the secondary things of human existence according to the rule of revelation and not revelation by the rules of secondary things, such as reason, morality and the state (cf Barth 1933f:309). Theology needs to place its emphasis on observing the First Commandment as the Reformers have done. To them, revelation was an act of God. There could be no such thing as revelation through nature, history or reason. In its obedience to the First Commandment, theology can never allow revelation to be associated with reason, creation or human existence. In this lecture, Barth (1933f:312-314) reached the conclusion that theology had to be alert so as not to seek other gods, but in obedience has to serve the One and Only God. The struggle against "natural theology" is the struggle to obey this One and Only God who has revealed himself in Jesus Christ (Barth 1933f:313-314). In 1934 he would add that the problem in the Church is not about the difference of opinion regarding the Lord's Supper, but centred around the obligation to confess the First Commandment (Barth 1934a:6). In his autobiography How I changed my mind? Barth (1969:47) would add that "National Socialism means the conscious, radical, and systematic transgression of this First Commandment." According to him, it constituted a sin against God. Later in 1935 Barth (1957:219) spoke of the "Polytheismus der Deutschen Christen" (the polytheism of German Christians).

\footnotetext{
9 "The point of contact thus is: the imago Dei, the human race's being human, its humitas, followed by two earlier indicated moments: the power of speech and responsibility."
} 
By the end of 1933 another article, the Lutherfeier appeared. In this article Barth (1933d:3-7) focuses on the theology of the German Christians, who had the majority vote in the leadership of the German Evangelical Church (see Hüttenhoff 2006:492-514). He (1933d:20) accused them of teaching false doctrine ("Irrlehre"). His (1933d:20-21) protest is not only against their acceptance of the Aryan paragraph or their rejection of the Old Testament. He is not only objecting to the Arianism present in their application of Christology or the Pelagianism present in their interpretation of justification or sanctification, or the idol worship of the state in their ethics. His protest is primarily against their false doctrine of "natural theology".

Er muß sich grundsätlich [sic] dagegen (als gegen die Quelle aller einzelnen Irrtümer) richten, daß die Deutschen Christen neben der HI. [sic] Schrift als einziger Offenbarungsquelle das deutsche Volkstum, seine Geschichte und seine politische Gegenwart als eine zweite Offenbarungsquelle behaupten und sich damit als die Gläubigen eines "anderen Gottes" zu erkennen geben.

$(\text { Barth 1933d:20 })^{10}$

Barth (1933e:3-4) reiterated this criticism directed at German Christians in the "Vorwort" of his article Die Kirche Jesu Christi. In this article he criticized the German Christians for supporting the National Socialist government's policy of racism towards Jews. In his sermon on Romans 15:5-13, Barth (1933e:16) said that it should be borne in mind that Jesus too was a Jew. The Word of God is for everyone, be they heathen or Jew. No one can be excluded from the grace of God.

\subsection{His critique against the German Christians}

In his article, Fragen an das Christentum, published in the Zofinger

Centrallblatt in December 1931, he accused Hitler and Mussolini of Fascism that views race and nation as religion (Barth 1957:94). According to Barth the traces of an old "Naturreligion" are evident for all to see in Fascism. According to him (1957:97), God cannot be associated with such religion.

Barth launched his first critique against the "German Christians" with the publication of the Theologische Existenz heute, written on the eve of 25 June 1933. He even sent Hitler a copy of this article on 1 July 1933 (see Busch

\footnotetext{
10 "One has to, as a matter of principle, guard against it that, apart from the Holy Word, German Christians also recognize German nationhood, its history and political present as a second source of revelation, thereby revealing themselves to be the faithful/followers of 'another god'."
} 
1976:239-240). In this article he openly criticized the German Christians and Hitler's role in the German Evangelical Church. He urged theologians not to neglect their task in proclaiming the Word of God within the Church as preachers and teachers. Theological existence means to be in mutual agreement with the Church's calling to proclaim the Word of God. The Word of God will overcome and triumph over any event, as has already happened in the life, suffering, death and resurrection of Jesus Christ. It is agreed within the Church that the Word of God must be heard and obeyed. It is also generally agreed that God reveals himself only through his Word, namely Jesus Christ. According to Barth, being part of theological existence in what was the present day then, meant that preachers, theologians and teachers would be in agreement with the abovementioned. However, there were those theologians who had lost their existence as theologians and teachers the moment they forgot their primary call and sought other goals. This is what happens when people succumb to human fears instead of trusting God's Word.

$\mathrm{Da}$ wir unter dem stürmischen Eindruck gewisser 'Mächte, Fürstentümer und Gewalten' Gott noch anderswo suchen als in seinem Wort und sein Wort noch anderswo als in Jesus Christus und Jesus Christus noch anderswo als in der heiligen Schrift Alten und Neuen Testaments und ebendamit solche sind, die Gott gar nicht suchen.

(Barth 1933a:6) $)^{11}$

In this instance theologians become people who no longer seek God. When the church's proper vocation becomes entangled with other vocations, her first and foremost vocation becomes hopelessly lost. This leads to disagreement within the church. When theologians and teachers are more faithful to other vocations, they stop being theologians or teachers of the church. The other vocation Barth is referring to in this instance is the political one. When theologians are more faithful to the political situation of the day, they become politicians or church politicians in Barth's opinion (Barth 1933a:6-7). This should never happen to theologians. In the church, the Word of God must be obeyed at all cost.

Barth (1933a:7-11) then described the problems he identified within the German Evangelical Church of the day. The German Evangelical Church

\footnotetext{
11 "That we, under the violent impression of certain 'powers, kingdoms/regimes and authorities' seek God elsewhere than in Jesus Christ and Jesus Christ somewhere else than in the Holy Word of the Old and New Testament, mean that we are like those who do not seek God at all."
} 
called for the reformation of the church in order for it to become one with the National Socialist state. According to Barth, the church can only reform in obedience to the demands of the Word of God. As far as Barth is concerned, the church of Christ can never be one with the state. The church needs to listen to God's Word and has to ignore the voice of politics (cf Barth 1933a:12).

The second problem Barth had, concerned the appointment of a "Reichsbischof", a Roman Catholic custom which is alien to the Reformed Churches (Barth 1933a:14-19). Had such "Reichsbischof" fulfilled an administrative role such as that of a "Generalsuperintendent", it could have been tolerated. However, when this "Reichsbischof's" role was the same as that of a Roman Catholic bishop, that is one with pre-eminence, one who is given special prerogatives and power of decision with regard to almost every conceivable issue, then it becomes problematic. According to Barth the notion of a "Reichsbischof" was an invention of the State to control the church according to government standards. In this instance, the "Reichsbischof" fulfilled the task of a government official, in the mould of Hitler's leadership pattern (Barth 1933a:19-21).

The third problem Barth highlighted had to do with the "Faith movement of the German Christians" (see Barth 1933a:21-26). He criticized them:

- for motivating the German people to find their way back to the church, instead of urging them in the church to obey and listen to the Commandment and promise of the free and pure Word of God (Barth 1933a:24);

- for misleading the German people by telling them to listen to a calling other than that from Christ as it is proclaimed through the Word of God according to the Bible. To Barth (1933a:24) the proclamation of God's Word is the church's task and role;

- for advocating the German Evangelical Church as the church in service of the German people. According to Barth (1933a:24), the church lives and exists in the service of the Word of God;

- for its view that the German Evangelical Church can believe in the divine authority of the State. To Barth (1933a:24), the church cannot believe in any state, be it the German State. According to him, the church proclaims the Gospel in all kingdoms, including the Third Reich. The church does so in accordance with the authority of God and not in the spirit of the State; 
- for wanting to expand the Church's Confession of faith to include the National Socialist's worldview. As far as Barth was concerned (1933a:24), the church's Confession of faith can only be expanded according to the criterion of the Bible;

- for making blood and race the criteria for membership of the German Evangelical Church. In Barth's view (1933a:24) a church ceases to be a Christian church if blood and race form the basis for her fellowship. This was in response to the Aryan paragraph, which excluded Christian Jews as members of the German Evangelical Church. Membership and fellowship of the church can only be determined by the Holy Spirit and through Baptism;

- for electing a "Reichsbischof" on political grounds (Barth 1933a:25);

- for transforming the training and leadership of the ministry into community work, instead of focusing on the proclamation of God's Word according to the Bible (Barth 1933a:25).

(Barth 1933a:25)

Barth explicitly left this list open-ended to emphasize the fact that his critique was not exhaustive. He also criticized the church in general for not taking any action against or resisting the notions of the "German Christians". In this article Barth predicted that the German Evangelical Church would completely succumb to the demands of Hitler through the acceptance of the "Reichsbischof", Müller and the German Christians. He furthermore castigated the counter- movement within the German Evangelical Church, the "JungReformatorische Bewegung" for not resisting the "Deutschen Christen", because in principal they agreed on the nature of the church (Barth 1933a:30). All that is required of the church, is to maintain the sovereignty of the Word of God in her preaching and theology. For this reason, Church people should unite against the "deutschen Christlichkeit und Kirchlichkeit" (Barth 1933a:35) and should work and pray for a "geistliches Widerstandszentrum" (spiritual centre of resistance) (Barth 1933a:36).

He emphasized the fact that the church needed to affirm and reiterate her Creed in word and deed. If the Church had any rivals, it needed to be confessed in concrete form.

Wiederhole und bekräftige man es auch in der Gemeinsamkeit der Gemeinden untereinander, wo diese Gemeinsamkeit wirklich die Gemeinsamkeit der Gemeinden des Glaubens und nicht die 
Gemeinsamkeit eines kirchenpolitischen Betriebs ist. Wo das Bekenntnis ist, da ist die eine heilige Kirche im Kampf mit dem Irrtum, in welchem sie nicht unterliegen wird.

(Barth 1933a:37). ${ }^{12}$

He said that theologians had to stay truthful to the mission entrusted they are entrusted with, namely to obey the Word of God. Theologians cannot follow other ideals and aims that are alien to or in opposition to God's Word. When this happens, a sin is committed not only against God, but also against the people.

He concluded his article with a final warning. According to him, the church and theology form the boundaries of the State (Barth 1933a:40). The church has to proclaim deliverance and salvation to all people. However, the church and the State must know that they could never bring salvation about as it comes solely from God. The State must allow the church to be truthful to her function (the proclamation of God's Word), while the church has to be willing to be true to her calling (Barth 1933a:39-40).

In his lecture, Reformation als Entscheidung, given on 30 October 1933, Barth declared that there could be no attempt to be part of the leadership of the German Evangelical Church, since it only consisted of members who were part of the "Faith movement of the German Christians". In his introduction he said that being part of the leadership, implied conformity to heresy and abuse of power. According to him, it was impossible to partake in the leadership of this "schwerkrank gewordene Kirche" (the critically ill church) (Barth 1933c:3). In the meantime, one could only be involved in the life of the congregation, through the offices of the church, in the proclamation of the Word and in practising theology. To quit the church or to form a new "Freikirche" would be irresponsible, unless God willed it (Barth 1933c:4). The Christians in Germany should unequivocally opt for the principles of the Reformation namely:

- that God reveals himself through Jesus Christ in His Word;

- that salvation and justification are only possible through the grace of God by faith alone;

The Christian church in Germany had to proclaim the Word of God at all cost. Its proclamation could never become a philosophy or the unfolding of an approach to life. No other doctrine or theology has a place in the church.

\footnotetext{
12 "(Let us) repeat and confirm it in the mutual communion of congregations, there where this communion is truly the communion of congregations of the faithful and not the communion of a church-political enterprise. Where this confession exists, that is where the one holy church is in a struggle against the heresy to which she will not succumb."
} 
According to Barth (1933c:22), the Holy Church is present there where the Word of God is heard and proclaimed (cf Barth 1933b:19).

Soon after this article was published, Barth's predictions proved true when the German Christians convinced the church to become one with the State with the appointment of the "Reichsbischof " and the acceptance of the "Aryan paragraph" by the German Evangelical Church on 4 January 1934. The Confessing Church began to emerge and continued to offer resistance to the onslaught on the character of the Church of Christ by the German Christians with the help of the Nazi state. The resistance culminated in the First Confessional Synod of the German Evangelical Church in Barmen, held on 3 and 4 January 1934 (see Barth 1934a:3-4). At this conference all 320 delegates from the 167 Evangelical Reformed and Evangelical Lutheran congregations in Germany rejected the theology or doctrine of the German Evangelical Church and reached an agreement in terms of which they declared their belief in the unity of their faith, hope and love (Barth 1934a:5, 915). According to Barth (1934a:6), the differences between them (the Evangelical Reformed and the Evangelical Lutheran congregations) should not be ascribed to Luther or Calvin, but rather to the fathers of the Union of the nineteenth century, such as Schleiermacher, Rothe and Beyschlag. In this regard, Barth (1934a:7) made it clear that Luther and Calvin should not be played off against one another, because the theologies of both were being abused by the German Christians, for instance the orders of creation and the "Theologumenon vom autoritären Bischof" by Luther and the rationalism of Calvin (Barth 1934a:7).

This unity among the Evangelical Reformed and Evangelical Lutheran traditions led to the second synod held in Barmen from 29 to 31 May 1934. At this synod a declaration was drafted in terms of which the Confessing Church openly declared the German Christians' doctrine as heresy and the official church as heretical (see Hunsinger 2000:60-61; see Trowitzsch 2006:5). With the exception of one sentence, this declaration was the work of Barth. In this declaration he reiterated what he had said in a previous article, Theologische Existenz heute, namely that:

- the Word of God is the only source of God's revelation (Gollwitzer 1964:7; see Hunsinger 2000:79);

- believers in the redemption through Jesus Christ belong body and soul to Him, their faithful Saviour, thereby excluding any possibility of belonging to other lords or creatures (Marquardt 1964:19; see Hunsinger 2000:80); 
- the Christian Church is the community of believers that acts in the world through Jesus Christ in his Word and Sacraments with the guidance of his Holy Spirit (Hamel 1964:45);

- the State does not have the authority to appoint any official with executive powers for the church (Jacob 1964:58);

- the church cannot become a vehicle of the State by assuming the nature, tasks and dignity that belong to the State (Barth 1946:35; Kupisch 1964:69; see Webster 2000:151);

- the church cannot place her Word and work in the service of selfchosen desires and purposes (Karnetzki 1964:87).

According to this declaration, the church is the community of believers, belonging in Word and Sacrament to Jesus Christ through His Holy Spirit. "With both its faith and its obedience, with both its message and its order, it has to testify in the midst of the sinful world, as the Church [sic] of the pardoned sinners, that it belongs to him [sic] alone and lives and live by his [sic] comfort and under his direction alone, in expectation of his appearing" (Jüngel 1992:XXV).

In the article, Offenbarung, Kirche, Theologie, written in April 1934, Barth accused the leadership of the German Evangelical Church of a lack of spiritual and intellectual authority (cf Barth 1934b:1). He also denied allegations in the Swiss press which stated that the "Pastors' Emergency League" was on its way out and German Protestantism was on its deathbed (Barth 1934b:2). It was obvious to Barth (1934b:2) that the struggle and resistance continued amongst the Confessing Church with the one Free Confessional Synod following the other. After reading the book, Die gegenwärtige geistige Lage im Spiegel philosophischer und theologischer Besinnung by Hirsch, a German Christian, Barth accused him of political theology. According to Barth (1934b:2), his interpretation of the present situation or "deutsche Stunde" (German hour) as a "Gottesbegegnung" (Divine encounter) was false (see Hein 2007:44-58). As far as Barth (1934b:4) was concerned, this theme also underlay the German Christians' doctrine and the "Reichsbischof" Müller's church governance, which amounted to nothing but extremism.

Jenem Irrtum ist entgegenzuhalten:das christliche Zentrum, das der theoretische und praktische, innere und äußere Grund der Kirche und der Gegenstand der Theologie ist: das Wort Gottes oder Jesus Christus, der Gekreuzigte und Auferstandene, steht als Herr, als Schöpfer, als Versöhner, als Erlöser über jenem bewegten Auseinander und Ineinander 
von Germanentum und persönlichem Christentum, mit dem es jene Anschauung allein zu tun hat.

(Barth 1934b:4-5) ${ }^{13}$

It was simply impossible to interpret the "deutsche Stunde" as a "Gottesbegegnung". God determines his own hour. His boundaries do not coincide with a specific moment of Christian and German truth. He sets his own boundaries. He cannot be manipulated. He is only interested in the believer's faith and obedience. He remains God. Only from Him and by sheer grace, can the sinner receive justification and sanctification (Barth 1934b:5):

Kirche ist da und nur da, wo Gott so und dort gesucht wird, wie und wo er gesucht sein will, das heißt aber in der Bindung an seine Zeugnisse, in der Erinnerung, Erforschung, Auslegung und Anwendung jener Botschaft des Alten und neuen Testamentes, die die Kirche ganz allein begründet hat und die sie auch ganz allein erhalten kann und je und je ganz allein erneuern will und wird. ${ }^{14}$

The quest for God is bound to the Bible which represents and differentiates the church as church. The church can only live on the one Word of God and on no other word. Barth (1934b:6) accused the "Reichsbischof" and the German Christians of not listening to the only Word of God. In a later article, Der gute Hirte, written on 4 May 1934, Barth stated that the church's governance under the "Reichsbischof" continued to exchange loyalties between Christian and political motives. According to Barth (1934c:4) God allows heresy in the church so that the church can decide to stand its ground and to test the truth of its being.

\subsection{His views on the church}

In a lecture entitled, Die Not der evangelischen Kirche, given in Berlin, Bremen and Hamburg, Barth said that the true evangelical church was the church which existed under the cross (Barth 1931:91). It was constituted by God through the sacrifice of Christ (see Welker 2006:137).

\footnotetext{
13 "That heresy is to be countered: the centre of Christianity, which is the theoretical and practical, the internal and external basis of the church and the subject of theology: the Word of God, in other words Jesus Christ, the Crucified and Risen, who as Lord, Creator, Conciliator/Mediator, Saviour is exalted above that agitated separating and coming together of Germanic culture and personal Christianity with which the heresy is solely dealing with."

14 "Church is there and only there where God is sought, there where and in the manner in which He wants to be sought, in other words obedience to His Revelation in the memory, research, exegesis and application of the very message of the Old and New Testament, the message solely upon which the church is founded and only which can maintain it, and only it can and will renew it."
} 
In an article, Fragen an das Christentum, (December 1931) Barth states that the church of Christ exists where the Word of God is heard (Barth 1957:98-99; see Webster 2005:30). It is only when it hears the Word of God and not that of State propaganda, that the church does missionary work, preaches forgiveness and the freedom of the Gospel in Christ and this she does through sheer grace (Barth 1957:99). Then the message of the church becomes the Christmas gift of grace and is not just an ideal.

After writing Fides quaerens intellectum, Barth was convinced of the need to write yet another book. He therefore, began to write Die kirchliche Dogmatik. He called it a new book as a way of expressing his dismay at his former friends (Brunner, Bultmann and Gogarten), by stating in a "new" book that he differed from them without naming them (cf McCormack 1997:447). The title of this book suggests that Barth wanted to stress the importance of the church (see Axt-Piscalar 2006:437-440, 450) and this becomes obvious when reading the first chapter of Die kirchliche Dogmatik, Vol. I/I. "Dogmatik ist eine Theologische Disziplin. Theologie ist aber eine Funktion der Kirche" (Barth 1932a:1; cf Van Erp 2007:9). ${ }^{15}$ The church confesses God when she proclaims the Word of God in faith, serves the Sacraments, in fellowship and worship, in her teaching and in reaching out to the sick and those in danger. But this action does not correspond with the reality of the church. The church is about God and his Word. Its action is theology (cf Mostert 2001:80-81). When the church confesses God, she also confesses her own humanity and her responsibility. The church realizes that she is accountable to God. He (1932b:196) added that the church's mission in the world is to let everyone share in the Word of God. Mission is a function of the church. The only difference between mission and theology is the difference of service.

In his lecture Für die Freiheit des Evangeliums, given on 22 July 1933, he said that the Church was the "Gemeinde" (congregation) that was called into being by the "Evangelium" (Barth 1933b:4). This Gospel came from God's free grace. According to Barth (1933b:6) the church existed as a human community where the "Evangelium" was proclaimed and heard. The church needed to be free from any human venture (see Ruddies 2006:78, 80). Therefore, the church had to listen to the Word of God and not to the insights of human beings, revelations from the State, history or nature. "Über das Evangelium bleibt frei, so gewiß Gott selber frei bleibt. Und auch in der verwüsteten Kirche lebt dann verborgen die Kirche des Herrn unter denen, die

15 "Dogmatics is a theological discipline. Theology, however, is a function of the church." 
ihre Knien nicht beugen dem Baal, da, wo das einfältige und fröhliche Bekenntnis seines Namens ist" (Barth 1933b:16). ${ }^{16}$

On 30 October 1933 Barth gave a lecture called Reformation als Entscheidung at the Sing Academy in Berlin. In this lecture he examined the nature of the church of the Reformation. According to him, the newly established German Evangelical Church of 23 July 1933 was a false and sick church. The only Evangelical Church that existed was one where the primary concern was the true doctrine of the Christian truths. It was through faith alone that the church of the Reformation listened to the Word of God. The church of the Reformation built on the foundation of Jesus Christ and not on the superior grounds of revelation and intellect, faith and knowledge, Gospel and State (Barth 1933c:22). The German Evangelical Church needed to make a decision: if it chose to be a church of the Reformation with the Reformed Confessions and true Reformed doctrine as basis, it should change accordingly. However, should it not change, then believers should view it as a false church. Resistance then became an option. Barth (1933c:24) concluded his lecture with a citation of Calvin in which Calvin advised the church to remember that the Reformation of the church was God's work. God urged the church to proclaim his Gospel.

During the period10 to 12 April 1934, Barth gave three lectures in Paris, namely Offenbarung, Kirche, Theologie. In his lecture on the church he said that it was not an institution of God's revelation, one in which God's Will, his Grace and his Truth fall into the hands of mankind. The church acknowledges the free and sovereign Will of God. It is common knowledge in the church that the truth of God is not an object, but is something that becomes visible through faith alone. In the church God's Grace is worshiped through Christ. The church is in no way identical to the Kingdom of God. According to Barth (1934b:24) such thinking is a heresy inherited from Roman Catholicism.

The church is not a free society in which appearances, experiences and impressions have to be kept up. The church does not meet for reasons of personal gain or because of moral obligation. The church is not founded on the decisions of mankind. God chose to have a relationship with the human race. God reveals Himself to man and makes man His possession. "Nicht die gleiche Empfindung, Überzeugung nd Willensbildung führt die Menschen zur Kirche zusammen und hält sie als Kirche beieinander, sondern der gleiche Gott, der gleiche Christus, der gleiche Geist, die gleiche Taufe, der gleiche

\footnotetext{
16 "The Gospel remains free, as certainly as God remains free. And so within the ravaged church, the church of God remains hidden amongst those who do not kneel before Baal, there where His Name is confessed in all simplicity and joy."
} 
Glaube" (Barth 1934b:25). ${ }^{17}$ The church is not a religious society. With this statement, Barth (1934b:25) rejected the heresy of modern Protestantism.

According to him, both heresies destroy the true spirit of the church of Christ, because they expect too much of man and too little of God. "... Eine allein macht die Kirche zur Kirche, daß der Mensch hört, weil Gott und was Gott zu inm geredet hat" (Barth 1934b:26). ${ }^{18}$ The church must ask herself time and again if she is true to her calling. If she is not true to her calling, then she stops being church. The church does not exist where man is worshipped and not God.

The church, however, exists in the world that emphasizes her humanity, her worldliness and her profanity. Although she is in solidarity with the world, her uniqueness and difference come to the fore in relation to politics, art and science. In the church no other gods can be worshipped, no ideologies may be followed and the human is forced to see him/herself, as he/she is, alone and naked in the eyes of God. The world hates the church for this.

The church exists where humankind listens to the Word of God (see Barth 1933b:19). God makes Himself known to humans as the Lord who meets him/her with forgiveness, holiness, and promise through his revelation in Jesus Christ. No church could exist without this order of revelation from God. "Man beachte, daß diese Beziehung zwischen der heiligen Schrift und der Kirche, die Gründung der Kirche auf den felsen Petrus nicht weniger als die Offenbarung selber immer wieder als ein Ereignis, eine Handlung des ewigen Wortes und seines Heiligen Geistes zu verstehen ist" (Barth 1934b:29). ${ }^{19}$ The Word of God rules the church (see Barth 1934d:4-22). Therefore, the church has to be loyal to God and to His Word.

The church must live to serve others. There is no room for "menschlicher herrschaft" ("Human rule") in the church (Barth 1934b:30). Human control in the church would lead to "Klerikalismus". "Klerikalismus ist die Herrschaft derer, die über die Einheit von Natur und Gnade Bescheid zu wissen meinen. Keine Herrschaft kann gewaltiger sein als diese. Sie ist in allen ihren Formen echt und recht die Herrschaft des Antichrist" (Barth

\footnotetext{
17 "It is neither the same perception, conviction or deliberate learning that brings people to the church and holds them together as church, but the same God, the same Christ, the same Spirit, the same baptism, the same faith."

18 "There is only One who makes the church a church, so that man can hear because God spoke to Him and because of what God had said to Him."

19 "One acknowledges that this connection between the Holy Word and the church, the establishment of the church on the rock of Peter, is not less than Revelation itself which is always to be understood as an occurrence, an act of the Eternal Word and his Holy Spirit."
} 
1934b:33). ${ }^{20}$ The church is not the church of the pious, but the church of Jesus Christ. The church is not Jesus Christ. It only has faith in Him. The church is the body of Christ, with Christ being its head. Man could only repeat what God has said in the first place. There could be no unity between God and man or between nature and grace in the church. Jesus triumphs over any contrast that might exist in the church. The church proclaims Jesus Christ because it is her commission and her hunger for the Gospel can never be satisfied. Barth (1934b:33) wanted to make it clear that there can be no place in the Church of Christ for natural theology.

During February and March of 1935 Barth lectured at the University of Utrecht on the Apostles' Creed. These lectures were eventually published in a book called the Credo: Die hauptprobleme der Dogmatik dargestellt im Anschluß an das Apostolische Glaubensbekenntnis. Barth ([1935] 1946:120129) understood the confession "credo Sanctam ecclesiam catholicam, sanctorum communionem" in a unique way. In this work, he first dealt with the definition of the word "Kirche" (Church). Barth ([1935] 1946:120) said that the Greek word $\dot{\varepsilon} \kappa \kappa \lambda \eta \sigma i ́ \alpha$ means a gathering of people who are called upon. "Das germanische Äquivalent Kirche, kerk, church, ist nach meiner Meinung nicht, wie man gewöhnlich hört, eine verstümmelte Wiedergabe des griechischen

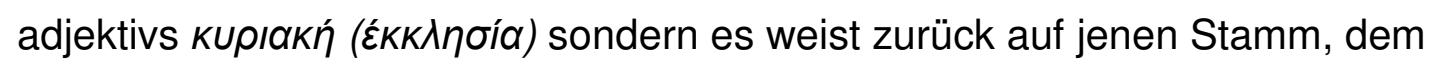
z.B. auch die lateinischen Vokabeln circa, circum, circare, circulus usw. angehören (Barth 1946:120). ${ }^{21}$ It refers to a specific place where the community meets. The church therefore is a meeting or assembly that takes place at a specific place and at a specific time, which happens recurrently (Barth 1946:120). The church is described by the supplementary clause sanctorum communionem that describes the church as a community, an assembly in which all who belong together are bound together in a unity. This community is defined by the double usage of the adjective sanctus, emphasizing the prominence of the assembly where it meets at a specific place and "the uniqueness of the shared matter: the sancta (holiness) which this communion is all about and with it the uniqueness of those belonging to this communion" (Barth [1935] 1946:120). The holiness of the church community implies her difference to the other communities that exist in the world (Barth [1935] 1946:121). The church does not follow or share in the

\footnotetext{
20 "Klerikalismus/clericalism is the rule of those who believe that they have real/true knowledge of the unity of nature and grace. No rule can be more powerful/awful than this. In all forms it is really and truly the rule of the antichrist."

21 "In my view, the Germanic equivalent Kirche, kerk, church, is not, a mutilated version of the

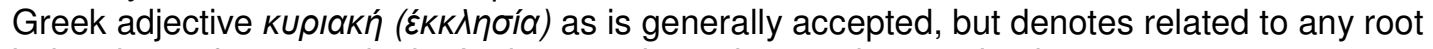
belonging to for example the Latin term circa, circum, circare, circulus etc."
} 
rules or aims of the other communities in the world. The church has no boundaries and its front lines run through the other communities. It has its own interest that is identical everywhere. It is also this common interest that binds the Holy Communion together as a unity.

Barth ([1935] 1946:121) said that the predicate catholica emphasizes this common interest of the church. The church is sancta and even ecclesia, but only when it is catholica. The church is in its core catholic. Everything else is secondary, given its nature. The church can only be holy when it is catholic in its core. Therefore, the Church must strive to be faithful to its catholicity. "Keine Bindung an ein Volk, einen Staat, eine Kultur darf sie dieses catholica vergessen lassen" (Barth [1935] 1946:121). ${ }^{22}$ Its founder Jesus Christ determines the church's holiness and catholicity. Barth ([1935] 1946:122) was convinced that the church's holiness and catholicity come to the fore in the foundation and governance of the church. One can hardly refer to the foundation of the church and ignore the leadership of the church. The one implies the other. "Sondern die Begründung der Kirche ist als solche auch die Einsetzung ihrer Regierung und wo immer gerade in der Praxis nach ihrer Regierung gefragt wird, da muss sofort, unmittelbar und in allem Ernst auf ihrer Begründung zurück gegriffen werden" (Barth [1935] 1946:122). ${ }^{23}$ The foundation of the Church is Jesus Christ who called the church into being when He filled his apostles with his Holy Spirit at Pentecost (Barth [1935] 1946:122). Jesus Christ gave his Holy Spirit to those who belong to Him so that the church can come to life on earth. This is what Barth alludes to when he describes the church as a place where the witness of the Bible determines its boundaries. It is also the place where Jesus Christ is present and is proclaimed through Biblical witness (Barth [1935] 1946:123). Jesus Christ is the only founder of the church and is its sole governor. "Er, Jesus Christus, regiert also die Kirche und keiner neben inm" (Barth [1935] 1946:122). ${ }^{24}$ The church cannot govern herself or let others govern her. Man did not create the church, which makes him unfit to govern the church. Therefore, man cannot regard him/herself as the lord of the church. Jesus Christ is the only Lord of his Church. He is the only one who can rule his church. According to Barth, ([1935] 1946:122) Jesus rules his church through his Word (Bible) that is the concrete witness of his words and deeds. He became flesh and chose, called and received all who believe in Him into unity with himself (Barth [1935] 1946:123). It is in [my emphasis] the church that the Bible is read and it is by

\footnotetext{
${ }^{22}$ "No bond with a nation, a state, a culture dare allow her to forget this catholica."

23 "However, as a result, the foundation of the church comprises her governance and in practice it means that whenever her governance is in question, one has to immediately, directly and in all seriousness fall back on her foundation."

24 "He, Jesus Christ and nobody but Him, thus governs the church."
} 
[my emphasis] the church that it is heard (see Webster 2005:30). The church's holiness and catholicity are revealed in its founder Jesus and through his leadership of his church.

According to Barth ([1935] 1946:124), the life and mission of the church provide a second proof of the church's holiness and catholicity. The life and the mission of the church are identical. The church is not an institution or an establishment and thereafter a communio sanctorum (Barth [1935] 1946:124). The life of the church is the mission she received and is fulfilling in everyday life. The church is in the same subordinate position that the limbs of a body are to its head. The church's very existence lies "in her captivity as a result of Christ's commission and in the implementation/execution of this commission" (Barth [1935] 1946:126). The declaration of this commission is found in Mathew 28:18-20. This commission includes the proclamation of the Gospel and the "Verwaltung der Sakramente" ("the ministering of the sacraments") (Barth [1935] 1946:126). It is in this reception and in the exercise of this one commission that the church is communio sanctorum, congregatio fidelium (Barth [1935] 1946:125). The church is holy and catholic through the commission of God. Everything that happens in the church is a different manifestation of obedience to this commission. The commission of God must be the power that leads and forms the church. The church that recognizes the great importance of this commission, will see to its own discipline and order. This discipline and order will not be randomly developed, but will be seen in the light of its commission. "Sie wird notwendig die Einheit der Kirche Christi damit respektieren, suchen und finden, daß sie sich offen hält für die Erkenntnisse und Erfahrungen, für den Rat und Beistand anderer, denselben Auftrag annerkennender Kirchen, daß sie sich bemühen wird, mit innen gemeinsam zu sprechen und zu handeln" (Barth [1935] 1946:126). ${ }^{25} \mathrm{~A}$ Church that lives in faith and obeys the commission of God is a living community.

A third proof of the church's holiness and catholicity lies in her acceptance of her fallen aim. "Die Kirche hat ihr Ziel genau dort, wo ihre Grenze ist" (Barth [1935] 1946:127). ${ }^{26}$ How do we know it? According to Barth ([1935] 1946:127-129) there are three ways, namely:

- we know the church only in its outward form, that is as the totality of those who are its members by their confession. The church is only known in its visible form as it appears on earth. Therefore, we confess

\footnotetext{
25 "By opening herself up to the insights and experiences, the advice and assistance of other churches that obey the same commission and by making an effort to speak the same language and act together, she will inevitably respect the unity of Christ's church, will look for it and find it."

26 "The church's goal is exactly there where her boundary is".
} 
credo ecclesiam. The church is called upon to be a visible church in the world. The church does not look beyond the visible church to some "civitas platonica" (Barth [1935] 1946:127). God through Jesus Christ is the Judge of the church. The church can look forward to meet this gracious Judge with confidence "auf Sieg der Gnade" ("to the triumph of mercy") (Barth [1935] 1946:127);

- we know the church in her imperfect form, in the form of the denomination in which one is baptised and reared. Other churches in which the one true church of Jesus Christ can be recognized, also exist. Barth [1935] 1946:128) acknowledges that it is sometimes possible for believers of a certain tradition to recognize their faith in the confessions of other churches or traditions. In this regard, he refers to the Lutheran Church as an example. But there are also other traditions, such as Roman Catholicism or traditions within the Evangelical Church itself, the "Synagoge des Neuprotestantismus" ("the synagogue of New Protestantism") in whose confessions one cannot recognize one's faith and therefore the one true church of Jesus Christ (Barth [1935] 1946:128). Then the believer must regard it as a false Church (see Barth [1935] 1946:128);

- we know the church only in its contrast to the Kingdom of God. The church lives in the time between the epiphany of Jesus Christ and God's coming Kingdom. The Kingdom of God is the boundary of the Church. The church awaits and yearns with hope:"'Dein Reich komme!' 'Und solange das Reich Gottes ihre Grenze ist, darf und muß sie es ertragen mit all dem, was dazu gehört, nur Kirche zu sein"' (Barth [1935] 1946:129). ${ }^{27}$

In July 1935 Barth gave four lectures in Geneva with the theme Die Kirche und die Kirchen. In these lectures he acknowledged the multiplicity of different churches that live in conflict with each other. For Barth there can be no excuse for the multiplicity of churches. There is only one church of Christ with only one imperative task namely to proclaim the good news to all the people that Jesus Christ has removed everything that separates them from God, even death. The church derives its being from this task. The church therefore has no life of its own, but lives as the one body of which the crucified and resurrected Christ is the head. The church has no commission other than this one. It is also true of every member who belongs in faith to this one body. Every member has the obligation to seek the unity of the church. Barth

\footnotetext{
27 "Let your Kingdom come! And for as long as the Kingdom of God is her boundary, she has to and must endure only to be church with all it entails."
} 
(1935a:6) admitted that the New Testament refers to a variety of gifts, communities and persons, but always in the context of the one Church. There are no polarities or tensions or mutual dependencies between the one church and the many gifts, communities and persons in the New Testament. There is only a one-sided relation of dependence and origin in terms of which the many are subordinate to the one. According to Barth (1935a:7), Paul did not speak of separate different churches, but rather referred to different factions or parties. Seeking the oneness of the church is not about a fixation of numbers, but is a quest to be obedient to the imperative content of the acknowledgeement that there is one Lord, one faith, one baptism and one God according to Ephesians 4:5. The quest for church unity can never be an attempt on itself, but is exactly the same as the quest for Jesus Christ as the concrete Lord and Head of the Church. "Jesus Christus als der eine Mittler zwischen Gott und Menschen ist geradezu die kirchliche Einheit, jene Einheit, in der es wohl eine Vielheit der Gemeinden, der Gaben, der Personen in der Kirche gibt, durch die aber eine Vielheit von Kirchen ausgeschlossen ist" (Barth 1935a:7). ${ }^{28}$ Barth (1935a:8) rejected the depiction of the multiplicity of churches as a mark of the visible church in contrast to the ideal, invisible and essential church, because it could not be biblically founded. He also rejected the explanation that the multiplicity of churches is a result of the unfolding of the wealth of the grace given to mankind in Jesus Christ.

According to him (1935a:10), the multiplicity of churches can never be explained, nor justified. It has to be condemned as sin. The only multiplicity that exists is that which exists within the church, namely the gifts of the Spirit, given to believers regardless of sex, language or race. Jesus Christ called his church to be one regardless of all the differences. The multiplicity of churches is a statement that the church has forgotten Christ. The church cannot listen to His voice without an act of decision, choice or confession. The church cannot decide or confess its faith without contradicting Him or falling into separation against Him. Barth (1935a:13) defined the church as the "assembly that knows that it is contradicting, a contradiction nevertheless of the One who is its Redeemer and who as Lord is greater than it is". The task of church union is only possible if we subject ourselves to the principle that in Christ alone this task is fulfilled. It is only His voice and command that can bring about union (Barth 1935a:20). When the church seeks union between different churches, this is the voice she needs to listen to. The church should always allow Christ to determine the relation with the State and allow His voice to speak out in every church matter (Barth 1935a:22-23). Barth's solution to the problem of multiplicity of churches lies in the fact that the

\footnotetext{
28 "Jesus Christ as the only intercessor between God and mankind undeniably is church unity, [a unity] in which there is a variety of congregations, talents and persons, but which excludes a multiplicity of churches."
} 
church needs to take serious its calling from Christ, needs to listen to His commands and must practise theology.

On 27 and 28 August 1935 Barth gave a lecture at the ministers' congress in Mysliborice (Mähren) entitled Die theologische Voraussetzungen kirchlicher Gestaltung. In this lecture Barth (1935b:3-28) paid attention to the importance of theology in the presupposition of the believer regarding the church. When enquiring about the preconditions of church establishment, "theological" can only mean one thing here: appropriateness, namely being in accordance with that which it is all about (Barth 1935b:21). Theology focuses on the identity of the being ("Sein") of the church. It reminds the church of the truth that must prevail in the church, the truth of God's grace through his revelation. Theology must always remind the church of its own true identity. The church is first of all a catholic church. It cannot be the possession of one specific nation or government (Barth 1935b:23). The church is holy because she belongs to Jesus Christ. The church is one in her confessions. The church is apostolic in her proclamation of God's revelation to all people.

Theology also reminds the church of Holy Scripture. Theology helps the church to understand Holy Scripture in order to find the real truth of God's existence (see Barth 1932a:284). Theology must remind the church of her founder, Jesus Christ. Everything that happens in the church must acknowledge this truth (see Barth 1932a:2-4).

\section{LESSONS TO BE LEARNED}

Barth's views on ecclesiology can be regarded as being too subjective and contextual. However true this may be, his views can help the church of today to avoid the same mistakes. His views serve as warning to every church to not forget the real character of the church of Christ. The Church stands under the cross of Jesus Christ as its only foundation.

In a time of great political unrest in South Africa, the Nederduitsch Hervormde Kerk van Afrika finds itself at a crossroad where serious issues have to be resolved. One of them is the notion of the Nederduitsch Hervormde Kerk van Afrika as a "volkskerk". During the coming synod (September 2007), the issue of whether this church needs to define herself by an exclusivist adjective in its church order, "Ordereël 4", will be profoundly debated. In the light of Barth's views on the church, it seems almost impossible for the Nederduitsch Hervormde Kerk van Afrika to continue defining herself as a "volkskerk" (see Barth [1935] 1946:121; see NHKA 2006). 


\section{Works Consulted}

Axt-Piscalar C 2006. Kontinuität oder Abbruch?: Karl Barths Prolegomena zur Dogmatik im Lichte der Theologie des 19. Jahrhunderts - eine Skizze. ThZ 62, 433-451.

Barth, K [1922] 1924. Der Römerbrief. 2. Auflage. München: Chr. Kaiser Verlag. Barth, K 1930a. Quousque tandem ...? ZZ 8, 1-6.

Barth, K 1930b. Die Theologie und der heutige Mensch. ZZ 8, 374-396.

Barth, K 1931. Die Not der evangelischen Kirche. ZZ 9, 89-122.

Barth, K 1932a. Die Kirchliche Dogmatik, Vol I/1, Die Lehre vom Wort Gottes:

Prolegomena zur kirchlichen Dogmatik. Zürich: Evangelischer Verlag A G Zollikon.

Barth, K 1932b. Die Theologie und die Mission in der Gegenwart. ZZ 10, 189-215.

Barth, K 1933a. Theologische Existenz heute!, TEH 1, 1-44.

Barth, K 1933b. Für die Freiheit des Evangeliums. TEH 2, 1-16.

Barth, K 1933c. Reformation als Entscheidung. TEH 3, 1-24.

Barth K 1933d. Lutherfeier 1933. TEH 4, 1-21.

Barth, K 1933e. Die Kirche Jesu Christi. TEH 5, 3-24.

Barth, K 1933f. Das erste Gebot als theologisches Axiom. ZZ11, 297-314.

Barth, K 1934a. Gottes Wille und unsere Wünsche. TEH 7, 3-39.

Barth, K 1934b. Offenbarung, Kirche, Theologie. TEH 9, 3-43.

Barth, K 1934c. Der gute Hirte. TEH 10, 3-23.

Barth, K 1934d. Der Dienst am Wort Gottes. TEH 13, 3-22.

Barth, K 1934e. Nein! Antwort an Emil Brunner. TEH 14, 4-63.

Barth, K 1935a. Die Kirche und die Kirchen. TEH 27, 3-44.

Barth, K 1935b. Die theologischen Voraussetzungen kirchlicher Gestaltung. TEH 28, 3-28.

Barth, K [1935] 1946. Credo: Die Hauptprobleme der Dogmatik dargestellt im Anschluß an das Apostolische Glaubensbekenntnis. Zürich: Evangelischer Verlag A G Zollikon.

Barth, K 1939a. David Friedrich Strauß als Theologe, 1839-1939. ThSt(B) 6, 3-35.

Barth, K 1939b. The church and the political problem of our day. London: Hodder \& Stoughton.

Barth, K 1944. The church and the war, tr by A H Froendt. New York: Macmillan.

Barth, K 1945. Die Evangelische Kirche in Deutschland nach dem Zusammenbruch des Dritten Reiches mit einer Predigt von Oscar Farner über Markus 10, 41-45, einem Eröffnungswort von Paul Vogt und zwei Beilagen. Zürich: Evangelischer Verlag A G Zollikon.

Barth, K 1946. Christengemeinde und Burgergemeinde. ThSt(B) 20, 3-43.

Barth, K 1957. Theologische Fragen und Antworten:Gesammelte Vorträge. 3. Band. Zürich: Evangelischer Verlag A G Zollikon.

Barth, K 1969. How I changed my mind? Edinburgh: Saint Andrew Press.

Barth, K [1931] 1981. Fides quaerens intellectum:Anselms Beweis der Existenz Gottes im Zusammenhang seines theologischen Programms. Zürich: Theologischer Verlag.

Barth, K 1982. Die Christliche Dogmatik im Entwurf, Vol 1, Die Lehre vom Worte Gottes. Zürich: Theologischer Verlag.

Bowden, J S 1983. Karl Barth: Theologian. Philadelphia, PA: Trinity. 
Brunner, E 1934. Natur und Gnade: Zum Gespräch mit Karl Barth. Tübingen: JCB Mohr.

Brunner, E [1946] 1972. Dogmatik, Band 1. Zürich: Theologischer verlag.

Busch, E 1976. Karl Barths Lebenslauf: Nach seinen Briefen. 2. Auflage. München: Chr. Kaiser Verlag.

Gijmink, G J H 1962. Inleiding tot de theologie van E Brunner. HTS 18(3), 59-68.

Gollwitzer, H 1964. Gottes Wirklichkeit und die Ideologien der Menschen, in Ein Ruf nach Vorwärts Barmen - 30 jahre darnach. TEH 115, 7-18.

Green, C 1989. Karl Barth: Theologian of freedom. London: Collins.

Hamel, J 1964. Gebundene oder Freie Kirche?: In ein Ruf nach Vorwärts Barmen - 30 Jahre danach. TEH 115, 45-57.

Hein, M 2007. Die Stunde der Entscheidung ist da - Bekennende Kirche und Schule im Nationalsozialismus. ZThK 104(1), 44-58.

Holmes, C R J 2007. Revisiting the doctrine of the divine attributes: In dialogue with Karl Barth, Eberhard Jüngel, and Wolf Krötke. New York: Peter Lang. (Issues in Systematic Theology 15.)

Hunsinger, G 2000. Disruptive grace: Studies in the theology of Karl Barth. Grand Rapids, MI: Eerdmans.

Hunsinger, G 2002. A tale of two simultaneities: Justification and sanctification in Calvin and Barth. ZDT 18(3), 316-338.

Hüttenhoff, M 2006. Ein Lehrer der christlichen Kirche: Karl Barths Kritik am Lutherbild der Deutschen Christen. ZThK 103, 492-514.

Jacob, G 1964. Autoritäre Kirchenführung?: In ein Ruf nach Vorwärts Barmen - 30 Jahre danach. TEH 115, 58-68.

Jüngel, E 1992. Christ, justice and peace: Toward a theology of the state. Ediburgh: T\&T Clark.

Karnetzki, M 1964. Auftrag und Freiheit der Kirche, in ein Ruf nach Vorwärts Barmen 30 Jahre danach. TEH 115, 87-97.

Kupisch, K 1964. Demokratie und Protestantismus: In ein Ruf nach Vorwärts Barmen 30 Jahre danach. TEH 115, 69-86.

Lindsay, M 2001. Dialectics of communion: Dialectical method and Barth's defence of Israel, in Thompson, G \& Mostert, C 2001:122-143.

McGrath, A E 2007. Theologie als Mathesis Universalis? Heinrich Scholz, Karl Barth und der wissenschaftliche Status der christlichen Theologie. ThZ63(1), 4457.

McCormack, B L 1997. Karl Barth's critical realistic dialectical theology: Its Genesis and development 1909-1936. Oxford: Clarendon.

Marquardt, F 1964. Entbindung zum Leben, In ein Ruf nach Vorwärts Barmen - 30 Jahre danach. TEH 115, 19-44.

Matheson, P (ed) 1981. The Third Reich and the Christian churches. Special American edition. Grand Rapids, MI: Eerdmans.

Meier, K 1976. Der Evangelische Kirchenkampf, Band 1: Der Kampf um die "Reichskirche". Göttingen: Vandenhoeck \& Ruprecht.

Molnar, P D 2005. Natural Theology revisited: A comparison of T F Torrance and Karl Barth. ZDT 21(1), 53-83.

Mostert, C 2001. Barth and Pannenberg on method, revelation and Trinity, in Thompson, G \& Mostert, C 2001:73-97. 
NHKA Kommissie van die AKV 2006. Voorstel tot die wysiging van Ordereël 1 en Ordereël 4 deur die Algemene Kommissie. Ongepubliseerd.

Niemöller, M 1939. Dennoch getrost: Die letzten Predigten. Zürich: Evangelischer Verlag A G Zollikon.

Price, D J 2002. Karl Barth's antropology in light of modern thought. Grand Rapids, Ml: Eerdmans.

Ruddies, H 2006. Einleitung. ZDT22(2), 75-81.

Sauter, G 2006. Was sagt die Barmer theologische Erklärung uns heute? ZDT 22(1), 718.

Scholder, K 1988a. The churches and the Third Reich, Vol 1, Preliminary history and the time of illusions 1918-1934, tr by J Bowden. Philadelphia, PA: Fortress.

Scholder, K 1988b. The churches and the Third Reich, Vol 2, The year of disillusionment: 1934 Barmen and Rome, tr by J Bowden. London: SCM.

Smid, M 1990. Deutscher Protestantismus und Judentum 1932/33. Munchen: Chr Kaiser Verlag.

Stoevesandt, H 1984. Theologische Existenz heute! Neu herausgegeben und eingeleitet von Hinrich Stoevesandt. Munchen: Chr Kaiser Verlag.

Thompson, G \& Mostert, C 2001 (ed). Karl Barth: A future for postmodern theology? Hindmarsh: Australian Theological Forum.

Trowitzsch, M 2006. Einleitung zum Symposion. ZDT 22(1), 5-6.

Van Erp, S 2007. Openbaring en integriteit: Een nieuwe context voor de systematische theologie. TTh 47(1), 3-15.

Webster, J 2000. Karl Barth. London: Continuum. [Outstanding Christian Thinkers.]

Webster, J 2005. Barth and the Reformed Confessions. ZDT 21(1), 6-33.

Welker, M 2006. Karl Barth und Dietrich Bonhoeffers Beiträge zur zukünftigen Ekklesiologie. ZDT22(2), 120-137. 